\title{
KECEMASAN PADA IBU HAMIL TERHADAP KUNJUNGAN ANC DI ERA PANDEMI COVID-19
}

\author{
Anxiety In Pregnant Mothers On ANC Visit In The Era Covid-19 Pandemic
}

\author{
Mega Silvian Natalia ${ }^{1}$, Tutik Ekasari ${ }^{2}$
}

${ }^{1}$ Stikes Hafshawaty Pesantren Zainul Hasan

Riwayat artikel

Diajukan: Agustus 2021

Diterima: September 2021.

PenulisKorespondensi:

- Mega Silvian Natalia

- Stikes Hafshawaty

Pesantren Zainul

Hasan

- nataliamega12@gmail . $\mathrm{com}$

\section{Kata Kunci:}

Ibu hamil, Kecemasan, Kunjungan ANC, Covid-19
Abstrak

Indonesia merupakan salah satu negara yang terjangkit pandemi Corona Virus Disease-19 (Covid-19) dengan angka kejadian terkonfirmasi Covid-19 (kasus baru) yang bertambah secara fluktuatif. Pemberian layanan maternal di masa pandemi perlu menjadi perhatian untuk menghindari terjadi peningkatan morbiditas dan mortalitas ibu, terlebih saat ini terdapat pembatasan pelayanan kesehatan maternal. Hal ini bisa menjadi faktor penyebab kecemasan yang terjadi pada ibu hamil. Tujuan dari penelitian ini untuk menganalisa hubungan antara kecemasan pada ibu hamil dengan kunjungan ANC di era pandemi covid-19. Rancang bangun penelitian ini adalah cross sectional. Populasi pada penelitian ini adalah semua ibu hamil yaitu sebanyak 37. Teknik Sampling dalam penelitian ini menggunakan total sampling. Sampel: semua ibu hamil yaitu sebanyak 37. Pengumpulan data dengan menggunakan kuesioner dan kecemasan diukur dengan HARS, dan dianalisa dengan Univariat dan bivariat dengan chi-square. Hasil uji statistik diperoleh nilai $\mathrm{p}=0,011$ sehingga dapat diartikan bahwa ada hubungan antara kecemasan dengan kunjungan ANC di era pandemi covid 19.

\section{Abstract}

Indonesia is one of the countries affected by the Corona Virus Disease-19 (Covid-19) pandemic with a fluctuating number of confirmed cases of Covid-19 (new cases). The provision of maternal services during the pandemic needs to be a concern to avoid an increase in maternal morbidity and mortality, especially when there are restrictions on maternal health services. This can be a factor causing anxiety that occurs in pregnant women. The purpose of this study was to analyze the relationship between anxiety in pregnant women and ANC visits in the era of the covid-19 pandemic. This is study with a cross sectional design. The population in this study were all 37 pregnant women. The sampling technique in this study used total sampling. Sample: 37 pregnant women. Data were collected using a questionnaire and anxiety was measured by HARS, and analyzed by univariate and bivariate with chi-square. The results of the statistical test obtained a value of $p=0.011$ so that it can be interpreted that there is a relationship between anxiety and ANC visits in the era of the covid 19 pandemic. 


\section{Pendahuluan}

Kecemasan atau stres pada ibu hamil dapat disebabkan oleh bebrapa faktor diantaranya rasa ketidaknyamanan selama kehamilan, pekerjaan, kekhawatiran pada proses persalinan, perubahan hormon serta kondisi bayi. Hasil studi melaporkan bahwa berdasarkan keterangan yang diperoleh dari ibu hamil dengan stres, berbagai macam masalah yang mereka alami meliputi permasalahan ekonomi, keluarga, pekerjaan, serta rasa cemas terhadap kehamilan maupun persalinan (Taslim, Kundre and Masi, 2016). Terjadinya perubahan fisiologis pada masa kehamilan mengakibatkan kekebalan parsial menurun sehingga dapat berdampak serius pada ibu hamil, hal ini menjadi penyebab ibu hamil dijadikan kelompok rentan resiko terinfeksi Covid-19 (Liang \& Acharya, 2020).

Indonesia merupakan salah satu negara yang terjangkit pandemi Corona Virus Disease-19 (Covid-19) dengan angka kejadian terkonfirmasi Covid-19 (kasus baru) yang bertambah secara fluktuatif (Purnamasari \& Raharyani, 2020). Situasi pandemi Covid-19 ini meningkatkan kecemasan ibu hamil, bukan saja mencemaskan keadaan janinnya tetapi juga mencemaskan apakah ibu dan janin akan sehat bebas infeksi Covid-19, aman atau tidaknya dalam pemeriksaan kehamilan selama masa pandemi. Pandemi COVID-19 menyebabkan banyak pembatasan hampir ke semua layanan, termasuk pembatasan dalam pelayanan kesehatan maternal dan neonatal, seperti adanya pengurangan frekuensi pemeriksaan kehamilan dan penundaan kelas ibu hamil (Direktorat Kesehatan Keluarga, 2020). Kondisi-kondisi tersebut dapat menjadikan permasalahan secara psikologis bagi ibu hamil yang dapat menimbulkan kecemasan.

Pemberian layanan maternal di masa pandemi perlu menjadi perhatian untuk menghindari terjadi peningkatan morbiditas dan mortalitas ibu, terlebih saat ini terdapat pembatasan pelayanan kesehatan maternal.
Seperti ibu hamil menjadi enggan ke puskesmas atau fasiltas pelayanan kesehatan lainnya karena takut tertular, adanya anjuran menunda pemeriksaan kehamilan dan kelas ibu hamil, serta adanya ketidaksiapan layanan dari segi tenaga dan sarana prasarana termasuk alat pelindung diri. Untuk mengantisipasi perburukan layanan ibu hamil di masa pandemi Covid-19 maka dibutuhkan panduan pelayanan baik untuk ibu hamil bukan Covid-19, maupun ibu hamil yang dicurigai terinfeksi Covid-19.

Oleh sebab itu dengan adanya pandemi covid-19 banyak pembatasan yang dilakukan pemerintah untuk mengurangi angka kejadian covid-19, termasuk kesehatan ibu hamil. Sehingga peneliti tergerak untuk melakukan penelitan yang berjudul Kecemasan pada ibu hamil terhadap kunjungan ANC di era pandemi covid-19. Tujuan dari penelitian ini adalah untuk mengidentifikasi tingkat kecemasan ibu hamil, mengidentfikasi kunjungan ANC di era pandemi, dan menganalisa hubungan antara kecemasan pada ibu hamil dengan kunjungan ANC di era pandemi covid-19 yang dilakukan di Desa Karangbong Kecamatan Pajarakan Kabupaten Probolinggo.

\section{Metodologi}

Penelitian ini merupakan penelitian analitik yang menjelaskan hubungan antar variabel dengan menggunakan alat bantu berupa kuesioner untuk mengukur setiap variabel yang diteliti. Rancang bangun penelitian ini adalah cross sectional. Variabel penelitian diukur dalam suatu waktu sehingga diperoleh gambaran keadaan pada waktu tersebut. Penelitian ini dilakukan di desa karangbong. Populasi pada penelitian ini adalah semua ibu hamil yaitu sebanyak 37. Teknik Sampling dalam penelitian ini menggunakan total sampling. Sampel: semua ibu hamil yaitu sebanyak 37 . Pengumpulan data dengan menggunakan kuesioner dan kecemasan diukur dengan HARS (Hamilton Anxiety Rating Scale) 
dengan kriteria : tidak ada kecemasan (skor kurang dari 14), kecemasan ringan (skor 14 - 20), kecemasan sedang (skor 21 - 27) kecemasan berat (skor $28-41$ ), kecemasan sangat berat (42-56). serta dianalisa dengan Univariat dan bivariat dengan chi-square.

\section{Hasil dan Pembahasan}

A. HASIL

1. Distribusi karakteristik responden

\begin{tabular}{lcc}
\hline Karakteristik & Frekuensi & $\begin{array}{c}\text { Persentase } \\
\text { \% }\end{array}$ \\
\hline Umur & 2 & 5,4 \\
$<20$ tahun & 32 & 86,5 \\
$20-35$ tahun & 3 & 8,1 \\
$>35$ tahun & & \\
Pendidikan & & 2,7 \\
Dasar & 27 & 73 \\
Menengah & 9 & 24,3 \\
Tinggi & & \\
Gravida & 26 & 70,3 \\
Primigravida & 11 & 29,7 \\
Multigravida & $\mathbf{3 7}$ & $\mathbf{1 0 0}$ \\
\hline TOTAL &
\end{tabular}

Berdasarkan tabel 1 diatas menunjukkan bahwa sebagian besar umur ibu hamil berada di rentang 20 - 35 tahun sebanyak 32 ibu hamil $(86,5 \%)$, pendidikan ibu hamil sebagian besar di tingkat menengah sebanyak 27 ibu hamil (73\%), dan sebagian besar ibu merupakan primigravida yaitu sebanyak 26 ibu hamil (70,3\%).

\section{Distribusi karakteristik responden berdasarkan tingkat kecemasan}

Tabel.3 Distribusi Karakteristik Responden berdasarkan kunjungan ANC

\begin{tabular}{|c|c|c|}
\hline $\begin{array}{c}\text { Kunjungan } \\
\text { ANC }\end{array}$ & Frekuensi & Persentase \% \\
\hline Patuh & 26 & 70,3 \\
\hline Tidak patuh & 11 & 29,7 \\
\hline TOTAL & 37 & 100 \\
\hline
\end{tabular}

\section{Distribusi kecemasan dengan kunjungan ANC}

Tabel.4 Distribusi kecemasan dengan kunjungan ANC

\begin{tabular}{|l|c|c|c|c|c|c|c|}
\hline \multirow{2}{*}{$\begin{array}{c}\text { Tingkat } \\
\text { kecemasan }\end{array}$} & \multicolumn{2}{|c|}{ Yatuh } & \multicolumn{2}{|c|}{$\begin{array}{c}\text { Tidak } \\
\text { Patuh }\end{array}$} & \multicolumn{2}{|c|}{ Total } & \multicolumn{2}{|c|}{$\begin{array}{c}\text { val } \\
\text { ue }\end{array}$} \\
\cline { 2 - 7 } & $\mathbf{n}$ & $\mathbf{\%}$ & $\mathbf{n}$ & $\mathbf{\%}$ & $\mathbf{n}$ & $\%$ & \\
\hline $\begin{array}{l}\text { Tidak } \\
\text { cemas }\end{array}$ & 2 & 5,4 & 1 & 2,7 & 3 & 8,1 & \\
\hline Ringan & 14 & 37,8 & 2 & 5,4 & 16 & 43,3 & \multirow{2}{*}{0,0} \\
\hline Sedang & 6 & 16,2 & 0 & 0,0 & 6 & 16,2 & 11 \\
\hline Berat & 3 & 8,1 & 7 & 19 & 10 & 27 & \\
\hline $\begin{array}{l}\text { Sangat } \\
\text { berat }\end{array}$ & 1 & 2,7 & 1 & 2,7 & 2 & 5,4 & \\
\hline TOTAL & $\mathbf{2 6}$ & $\mathbf{7 0 , 2}$ & $\mathbf{1 1}$ & $\mathbf{2 9 , 8}$ & $\mathbf{3 7}$ & $\mathbf{1 0 0}$ & \\
\hline
\end{tabular}

Berdasarkan dari analisis bivariat menunjukkan bahwa dari 16 responden yang tingkat kecemasan ringan terdapat 14 $(37,8 \%)$ yang patuh melakukan ANC sedangkan dari 10 responden yang tingkat kecemasannya berat terdapat 7 (19\%) yang tidak patuh melakukan ANC. Hasil uji statistik diperoleh nilai $\mathrm{p}=0,011$ sehingga dapat diartikan bahwa ada hubungan antara kecemasan dengan kunjungan ANC di era pandemi covid 19.

\section{Hubungan antara kecemasan dengan} kunjungan ANC di era pandemi covid 19

Berdasarkan tabel 4 dapat diketahui hasil dari penelitian menunjukkan bahwa ibu hamil yang mengalami tingkat kecemasan ringan ada 16 orang dengan 14 orang patuh melakukan ANC, sedangkan 7 dari $10 \mathrm{ibu}$ hamil yang mengalami tingkat kecemasan berat dan tidak patuh melakukan ANC. Adapun hasil dari uji statistik diperoleh nilai $\mathrm{p}=0,011$ dimana menunjukkan adanya hubungan antara kecemasan dengan kunjungan ANC di era pandemi covid 19.

Kecemasan pada ibu hamil dapat berdampak pada kesehatan ibu dan janin. Dengan adanya pandemi Covid-19 dapat meningkatkan insiden atau tingkatan kecemasan pada ibu hamil, sehingga permasalahan tersebut memerlukan penanganan lebih lanjut, untuk mengurangi 
dampak negatif pada kesejahteraan ibu dan janin (Kajdy et al., 2020).

Kecemasan ibu hamil dalam melakukan kunjungan antenatal pada masa pandemi covid 19, baik dilakukan secara tatap muka maupun secara daring, pengkajian psikologis pada ibu hamil sangat diperlukan dan dapat dilakukan dengan optimal, sehingga permasalahan yang berhubungan dengan kecemasan segera dapat diatasi dan tidak akan menghambat kunjungan ANC untuk memeriksakan kesejahteraan ibu dan bayinya.

Hal ini juga didukung oleh penelitan (Yuliani, D. R., \& Aini, F. N. 2020) yang menyatakan bahwa ibu hamil yang mengalami kecemasan saat pandemi Covid19 mencapai 63-68 \%. Data menggambarkan bahwa $40 \%$ Dokter Obstetri Ginekologi pernah dihubungi oleh lebih dari sepuluh ibu hamil, karena kecemasan terkait Covid-19. Selain itu ada penelitian yang menyatakan bahwa Hasil uji statistik chi square diperoleh nilai $\mathrm{p} \mathrm{0,016}$ $(\mathrm{p}<0,05)$ maka dapat disimpulkan ada hubungan antara tingkat kecemasan ibu hamil dengan kunjungan antenatal care ke fasilitas pelayanan kesehatan di masa pandemi covid-19 (Sulistyowati, N. dan Yeti T, 2021).

Sebagai peneliti dalam melihat kondisi yang terjadi pada ibu hamil, maka perlu adanya pendekatan kepada ibu hamil melalui cara lain seperti membuat grup online sebagai pengganti media kelas ibu hamil, membuka konsultasi online, dan menganjurkan ibu melakukan kunjungan ANC apabila ada keluhan dengan tetap mematuhi protokol kesehatan. Hal ini dilakukan sebagai upaya agar pelayanan ANC nya tetap terpenuhi, sehingga ibu dan janin tetap dalam kondisi sehat meskipun di era pandemi covid 19.

\section{Simpulan}

Pada penelitian ini didapatkan hasil yang menunjukkan bahwa ada hubungan antara kecmasan ibu hamil dengan kunjungan ANC di era pandemi covid 19. Hai ini bisa ditunjukkan dengan hasil uji statistik yang menunjukkan $\mathrm{p}=0,011$. Dan diketahui pula bahwa sebagian besar ibu yang mengalami kecemasan ringan tetap patuh pada kunjungan ANC di era pandemi yaitu sebesar $37,8 \%$.

\section{Daftar Pustaka}

Direktorat Kesehatan Keluarga (2020) 'Pedoman Bagi Ibu Hamil, Ibu Nifas, dan Bayi Baru Lahir Di Era Pandemi COVID-19', pp. 9-12. Available at: http://www.kesga.kemkes.go.id/imag es/pedoman/Pedoman bagi Ibu Hamil, Bersalin, Nifas dan BBL di Era Pandemi COVID 19.pdf

Kajdy et al.,2020. "Risk Factors for Anxiety and Depression Among Pregnant Women During the COVID-19 Pandemic: A web-based crosssectional survey," Medicine (Baltimore),, vol. 99, no. 30, p. e21279, 2020

Liang, H., \& Acharya, G. (2020). Novel corona virus disease (COVID-19) in pregnancy: What clinical recommendations to follow? Acta Obstetricia et Gynecologica Scandinavica. https://doi.org/10.1111/aogs.13836

Purnamasari, I., \& Raharyani, A. E. (2020). Tingkat Pengetahuan dan Perilaku Masyarakat Kabupaten Wonosobo Tentang Covid-19. Jurnal Ilmiah Kesehatan, 10(1), 33-42. https://ojs.unsiq.ac.id/index.php/jik/a rti cle/view/1311 S

Sulistyowati, N. dan Yeti T. (2021). Tingkat Kecemasan Ibu Hamil Terhadap Kunjungan Antenatal Care Di Masa Pandemi Covid-19. Jurnal Kebidanan vol.13 no.1. http://ejurnal.stikeseub.ac.id/index.p hp/jkeb/article/view/423 
Taslim, R. W. R., Kundre, R. and Masi, G. (2016) 'Hubungan pola makan dan stres dengan kejadian hipertensi grade 1 dan 2 pada ibu hamil di wilayah kerja Puskesmas Kamonji Kecamatan Palu Barat', JURNAL KEPERAWATAN, 4(1).

Yuliani, D. R., \& Aini, F. N. (2020). Kecemasan Ibu Hamil Dan Ibu Nifas Pada Masa Pandemi Covid-19 Di Kecamatan Baturraden. Jurnal Sains Kebidanan, 2(2), 1114.https://doi.org/10.31983/jsk.v2i2. 64-87 